\title{
An Identification of Environmental Disturbances from Road Developments in Subarctic Muskeg
}

\author{
J.W. POMEROY ${ }^{1}$
}

\begin{abstract}
The location, nature, and magnitude of some environmental changes associated with the introduction of a road across a muskeg in the discontinuous permafrost zone are identified from examination of near-infrared Landsat images. Impedance of natural surface drainage by the presence of a roadbed is hypothesized to transmit upstream hydro-thermal changes through the muskeg terrain, which in turn cause change in the muskeg vegetation community. Differences among the near-infrared spectral reflectances of fen, black spruce bog, and Sphagnum bog communities are found sufficiently large for use as indices of differences in the actual biophysical natures of the muskegs.
\end{abstract}

Key words: environmental impact, northern Canada, muskegs, hydrology, Landsat interpretation, permafrost, road design

RÉSUMÉ. L'étude d'images de Landsat presque infrarouges révèle l'emplacement, le genre et l'amplitude de certains changements dans l'environnement associés à la construction d'une route à travers un marais dans une zone à pergélisol discontinu. L'auteur présente une hypothèse selon laquelle l'assiette de la chaussée ferait obstacle au drainage de surface normal, causant ainsi des variations dans la végétation du marais. Les différences en réflectance spectrale presque infrarouge entre la terre marécageuse, le marécage d'épinettes noires et le marécage de sphaigne sont d'une importance suffisante à servir d'indice dans la nature biophysique véritable du marais.

Mots clés: impact sur l'environnement, le nord du Canada, marécage, hydrologie, interprétation de Landsat, pergélisol, conception de routes

Traduit pour le journal par Maurice Guibord.

\section{INTRODUCTION}

Though pipeline construction and mineral developments have received greater public attention, the most extensive surficial modification resulting from northern development is the construction and maintenance of roads. Roads in much of the north must be built through muskeg, which is defined as organic terrain ranging from fen to bog. North of the $1^{\circ} \mathrm{C}$ mean annual air temperature isotherm, permafrost becomes prevalent in black spruce bogs, peat plateaux, and Sphagnum bogs (Brown, 1977). Farther north, in the zone of continuous permafrost, all types of muskeg contain perennially frozen ground. Even in the discontinuous zone, however, it is often impossible to avoid construction over muskegs containing permafrost (Savage, 1964).

Muskegs are sustained by a dynamic equilibrium of physiography, climate, hydrology, soil temperature, and vegetation. The disturbance of one of these factors can cause dramatic and extensive changes in the regional muskeg ecosystem (Brown and Péwé, 1973). Muskegs in the discontinuous permafrost zone may therefore be extremely sensitive to environmental impact. Roads built through muskeg can directly disturb regional surface drainage, local vegetation, and local soil thermal regime. This can lead to indirect disturbance of the soil thermal regime, soil composition, chemical content of surface water, vegetation, and wildlife on a regional basis, as the ecosystem adjusts to a new equilibrium.

When surficial flows of water perpendicular to a length of roadbed are greater than the ability of the roadbed to transmit them and the capacity of the upstream organic terrain to absorb them, ponding of water occurs in the upstream muskeg. This ponding can divert nutrient-rich water from fens or mineral terrain onto ombrotrophic bog terrain. Nutrients in this water decompose the bog, destroying its characteristic vegetative cover and soil composition. Continued ponding of surface water will degrade underlying permafrost, resulting in the development of thermokarst terrain. Under such conditions black spruce bogs develop "drunken forest" and eventually "collapse scar" morphologies (French, 1976). Changes to the geomorphic, hydrologic, and vegetative systems of a muskeg can be severe and extensive. Radforth (1977) notes that water in either the solid or liquid state is involved in all environmental disturbances of muskeg.

Highway engineers have developed several techniques to mitigate the environmental impact of roads built through perennially frozen muskeg. Thick embankments are constructed over permafrost to control the rate at which the underlying permafrost will thaw. Culverts and drainage tiles are installed to permit natural overland flow (MacFarlane, 1969).

There is evidence, however, that attempts to reduce the impacts of roadbeds on muskeg surface hydrology are often inadequate or lose their utility over time. Culverts can become blocked by beaver dams, filled with sediments and debris, or jammed with ice during spring runoff (FitzGibbon, 1979). Damming of surface flow in muskegs is noted by the Saskatchewan Research Council (1981) in its study of the Hanson Lake Road in northern Saskatchewan; drowning of bog vegetation occurs frequently along roads in northern Saskatchewan.

This experience indicates a need to monitor the environmental conditions along road development corridors in northern muskegs. The extensive potential changes in muskeg composi- 
tion resulting from the presence of roadbeds in large areas of muskeg suggest remote sensing of muskeg vegetation as a possible monitoring tool. Single spectral band Landsat satellite imagery is a relatively cost-effective means of monitoring vegetation communities. Field sampling or specially commissioned aerial photography can often be a prohibitively expensive means of monitoring large areas in remote regions (Krebs, 1982). Landsat imagery can be obtained for various dates and years for all the boreal forest in Canada and Alaska. Quenet (1980) concludes that Landsat imagery can be useful in forest change detection studies where current, low-resolution data are required and finds it particularly relevant to forestry data collection in the north.

Statistical procedures performed on quantified Landsat images are the most accurate methods of detecting significant changes in image tones over an area (Landgrebe, 1978). Digital values of tonal density recorded from a Landsat image represent an average of the spectral response of individual features in a surface mosaic. Statistics such as the cluster analysis and pattern recognition methodologies suggested by Swain (1978) require extensive data and processing time and are impractical given the computer facilities and budgets of many northern land managers. An approach using a powerful, physically based, easily performed statistical methodology is needed to broaden the range of researchers using Landsat data. Hazenberg and Cheliak (1980) suggest that a multifactor analysis of variance based upon linear models is appropriate for analyzing Landsat imagery, and it meets these requirements. Such a statistical test can be performed on a hand calculator or mini-computer, depending on the database size, and can be related to a linear model describing the physical changes being detected.

Digital tapes of Landsat images represent the most precise data source. However, incorporating these data into the required geographic information system is a major computerprogramming task, which limits the number of potential users. The resolution of such a system may be greater than necessary for detecting a large-scale change. A less costly method for studies requiring low resolution uses data collected, using a digital densitometer, from a black and white print of a single Landsat band. Digitization of tonal densities from such a print can detect differences in tone that are not apparent in visual inspection of the image. If tests are made which conclude that such data has the required accuracy and resolution, then the ease of transferring corroborative information, ease of handling, and low cost of prints make this procedure desirable (Mead, 1982).

The pilot study reported here demonstrates the identification of the location, nature, and magnitude of a probable environmental impact associated with the introduction of a road across a northern muskeg. The identification is made from a remote examination of muskeg vegetation and thus can only imply these parameters of change in a muskeg. Rigorous use of statistics, however, insures a low probability of error in the conclusions drawn. An analysis of variance (ANOVA) and other simple statistical tests are conducted on data collected from a Landsat print. The methodology developed to make conclusions regarding environmental impact can be applied by a wide range of land scientists and managers concerned with northern development.

\section{STUDY AREA}

The Mackenzie and Liard river valleys have been extensively mapped in terms of vegetation and permafrost (Forestry Management Institute, 1974), providing useful corroborative data for Landsat image analysis. The Liard and Mackenzie highways are major roads in northern Canada, intersecting near the confluence of the Liard and Mackenzie rivers (Fig. 1). The region southeast of Fort Simpson, Northwest Territories, is characterized by a mosaic of Sphagnum and black spruce bogs underlain by permafrost and wet fens without permafrost. Typical topographic gradients are $2.8 \mathrm{~m} / \mathrm{km}$ or less and surface relief is approximately $1 \mathrm{~m}$. There is considerable potential for development of thermokarst in the bog terrain (Environmental Assessment Panel, 1981).

The Mackenzie Highway in the study area was constructed between 1971 and 1973 in anticipation of a major oil pipeline development along the Mackenzie River valley. Construction of the Liard Highway from Fort Simpson to Fort Nelson, British Columbia, began in early 1978 and was completed in late 1983. Both highways are wide gravel roads with embankments at least $1 \mathrm{~m}$ thick. A consultant's report (Interdisciplinary Systems, 1981) identified deficiencies in the construction practices used for the Liard Highway. An estimated 56\% of the planned drainage tiles and culverts were actually installed in the roadbed. My own field investigation in June 1983 found major repairs in progress on the Liard Highway to replace culverts that were damaged by the spring freshet. No such reports of extreme damage due to inadequate culverts have been made on the Mackenzie Highway. This suggests that the Liard Highway may have a higher potential for flooding and disturbance of adjacent muskegs.

\section{DATA COLLECTION}

A 1:500 000 scale Landsat black and white print of band \#6 (near-infrared), taken on 18 September 1979, was used as a data source. The print is relatively cloud free and covers the Liard river valley from Fort Liard, N.W.T., to the confluence of the Liard and Mackenzie rivers. The Mackenzie Highway and the then-completed sections of the Liard Highway are visible on the image. The map in Landscape Survey and Terrain Susceptibility to Damage for the Southern and Central Mackenzie River Valley (Environment Canada, 1973) was used to determine areas of predominantly organic terrain.

Six test muskegs were selected for investigation. Two were on the Mackenzie Highway; four, two at a 9-month-old (recent) section and two at a 36-month-old (older) section, were on the Liard Highway. Two control muskegs, one on the thenundeveloped route of the Liard Highway and the other a local unimpacted muskeg, were included for comparison (see Fig. 1). This provided 16 experimental strips of muskeg, each either upstream or downstream of the roadway and all perpen- 


\section{LOWER LIARD RIVER VALLEY}

:-Z STUDY MUSKEGS

GRAVEL ROADWAY

........ PROPOSED ROAD

$\longleftarrow$ SURFACE DRAINAGE VECTOR
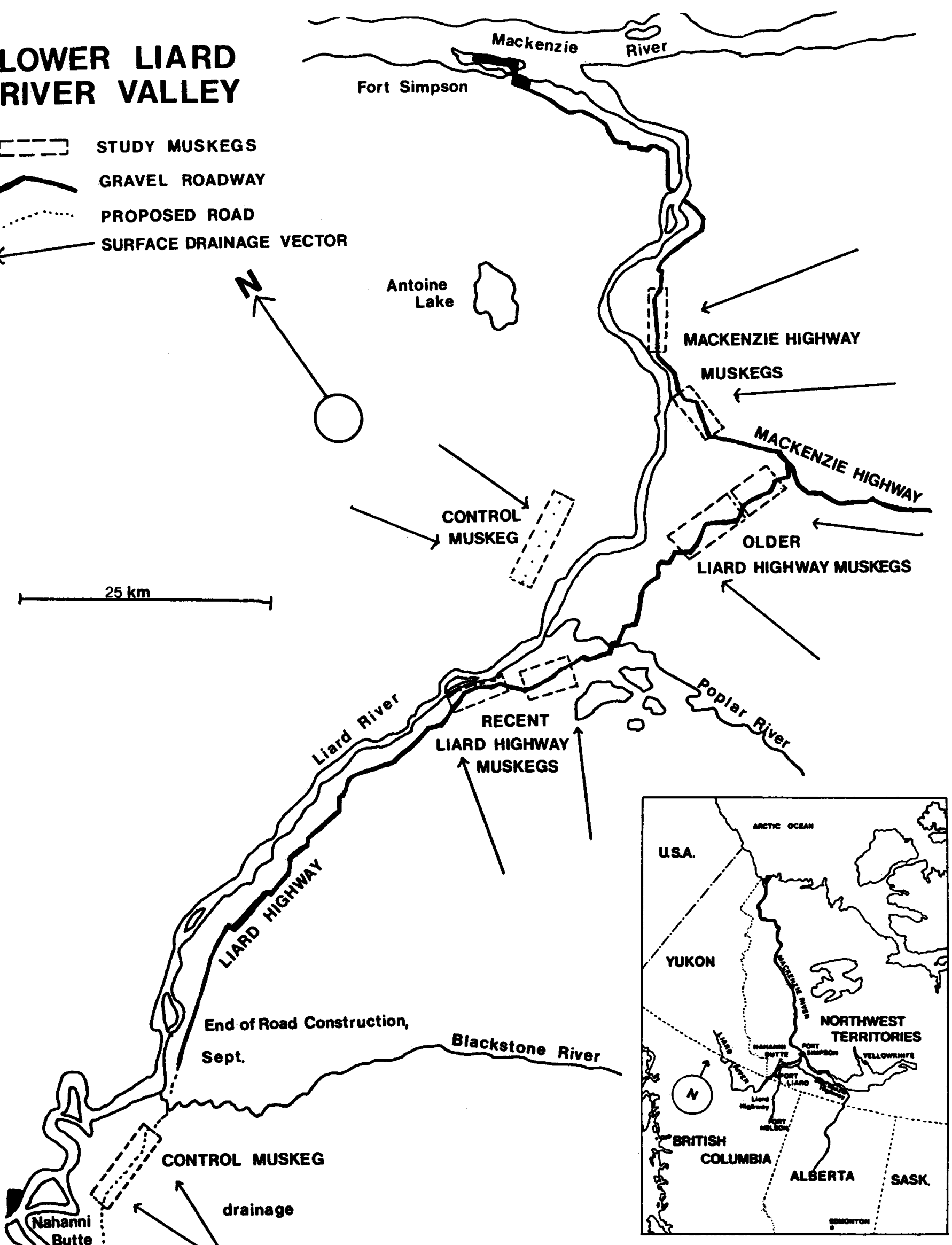

FIG. 1. Study area. Confluence of the Liard and Mackenzie rivers, 1979. 
dicular to drainage at the site. The areas of the strips vary from $4.13 \mathrm{~km}^{2}$ to $10.86 \mathrm{~km}^{2}$.

A Macbeth Gemini Model TR-527 digital densitometer was used to collect and quantify the tonal densities of the muskeg strips from the Landsat print. In each of the 16 strips, nine readings taken from random locations were collected. Each reading averages the spectral reflectance of $0.25 \mathrm{~km}^{2}$ of the muskeg. The proportional area sampled in each strip varies from $20.7 \%$ to $54.5 \%$. An extensive change in muskeg hydrology, vegetation, or morphology will alter the spectral reflectance value (tonal density) of the muskeg vegetation. The digital densitometer readings therefore represent muskeg conditions and can be compared to determine what effect, if any, the roads are having on adjacent muskegs.

The map, Vegetation Types of the Mackenzie Corridor (Forestry Management Institute, 1974), identifies seven categories of muskeg in the lower Liard River valley. To determine characteristic tonal densities of these muskegs, examples of the seven categories were transposed from the 1:125000 scale vegetation map onto the 1:500 000 scale Landsat print. Examples of the ecological categories were chosen from scattered locations near experimental muskegs but at sufficient distance for the roads to have no impact. Eight digital densitometer readings were taken from each muskeg ecological category on the Landsat print, in the same manner as they were taken from the experimental strips of muskeg. These readings characterize the near-infrared spectral reflectance of the ecological categories of muskeg found in the lower Liard River valley.

\section{TEST OF RESOLUTION}

To determine if there are sufficient differences between the infrared spectral reflectances of muskeg vegetation as recorded on a \#6 Landsat print, the tonal densities of seven ecological categories of muskeg were analyzed using iterations of Student's t-test. This analysis is used to group the ecological categories into classes whose tonal densities can be statistically distinguished from one another.

Data from each of the seven ecological categories were arranged in a $7 \times 7$ matrix, such that the distributions of each unique pair of categories were compared within an element of the matrix (see Table 1). The Student's t-test was used in this comparison because it is only concerned with a comparison of two distributions, is less prone to erroneously conclude that two distributions are different, and allows varying sample sizes. If it could be concluded at the 5\% level of significance that the distributions comprising a pair of categories were not different, then the two categories were grouped into a class. Iterations of the Student's t-test were performed from the most disparate pair of categories to the most similar. Following this procedure, four classes of muskeg were statistically distinguished (Table 2).

Examination of the classification shows that only small proportions of Sphagnum bog need be present in a muskeg (30\%) for the spectral response of the muskeg to approximate that of a pure $(100 \%)$ Sphagnum bog. However, pure $(100 \%)$ fens and black spruce bogs can be distinguished from each other and from muskegs that are a mosaic of the two.

Considering the sparse occurrence of Sphagnum bog in the study area, resolution of muskeg into four classes is considered sufficient for measuring vegetative changes from black spruce bog to fen.

\section{ANALYSIS}

Three hypotheses were made concerning the association between the presence of a roadbed and the muskeg vegetation communities along its length. They are:

a) Within a given muskeg, the variation in vegetation can be related to different ages (or absence) of a roadbed.

b) Muskeg vegetation on upstream and downstream sides of a roadbed differs in a similar manner at all sites; and

c) Variations in muskeg vegetation can be related to variations in the age of the roadbed and position upstream or downstream from the roadbed.

These hypotheses were combined in a linear statistical model, whose factors are proposed to explain the variance in the distribution of muskeg tonal densities. The model is:

$$
\mathrm{X}_{\mathrm{ijm}}=\mu+\alpha_{\mathrm{i}}+\beta_{\mathrm{j}}+(\alpha \beta)_{\mathrm{ij}}+\mathrm{e}_{\mathrm{ijm}}
$$
where:

TABLE 1. Matrix of differences between mean tonal densities for ecological categories of muskega

\begin{tabular}{|c|c|c|c|c|c|c|c|c|c|}
\hline & & & $(1)$ & $(2)$ & (3) & $\begin{array}{l}\bar{X}_{X} \\
(4) \\
\end{array}$ & $(5)$ & (6) & (7) \\
\hline \multirow{7}{*}{$\bar{x}_{\mathbf{y}}$} & $100 \%$ black spruce bog & (1) & 0 & 0.1774 & 0.1777 & 0.2427 & 0.3481 & 0.3510 & 0.3827 \\
\hline & $60 \%$ fen $/ 40 \%$ black spruce & (2) & $\mathbf{R}$ & $\mathbf{0}$ & 0.0003 & 0.0653 & 0.1715 & 0.1736 & 0.2053 \\
\hline & $70 \%$ black spruce/ $30 \%$ fen & (3) & $\mathbf{R}$ & $\mathbf{R}$ & $\mathbf{0}$ & 0.0650 & 0.1712 & 0.1733 & 0.2050 \\
\hline & $100 \%$ fen & (4) & $\mathbf{R}$ & $\mathbf{R}$ & $\mathbf{R}$ & $\mathbf{0}$ & 0.1062 & 0.1083 & 0.1400 \\
\hline & $70 \%$ fen/ 30\% Sphagnum bog & (5) & $\mathbf{R}$ & $\mathbf{R}$ & $\mathbf{R}$ & $\mathbf{R}$ & $\mathbf{0}$ & 0.0021 & 0.0338 \\
\hline & $60 \%$ black spruce/ $40 \%$ Sphagnum bog & (6) & $\mathbf{R}$ & $\mathbf{R}$ & $\mathbf{R}$ & $\mathbf{R}$ & $\mathbf{R}$ & 0 & 0.0317 \\
\hline & $100 \%$ Sphagnum bog & (7) & $\mathbf{R}$ & $\mathbf{R}$ & $\mathbf{R}$ & $\mathbf{R}$ & $\mathbf{R}$ & $\mathbf{R}$ & 0 \\
\hline
\end{tabular}

\footnotetext{
${ }^{a}$ Each element of the matrix represents $\left(\bar{X}_{x}-\bar{X}_{y}\right)$; R denotes a redundant value. Numbers ( ) representing levels of the $x$ axis correspond to numbers ( ) and ecological category names on the $y$ axis.
} 
$\mathrm{X}_{\mathrm{ijm}}=$ tonal density of the muskeg vegetation at digital densitometer reading $\mathrm{ijm}$,

$\mu \quad=$ grand mean muskeg tonal density,

$\alpha_{i} \quad=$ variation in the tonal density corresponding with the age and presence of the roadbed bisecting the muskeg (hypothesis a),

$\beta_{\mathrm{j}} \quad=$ variation in tonal density corresponding with the hydrologic relation of the road to the muskeg (hypothesis b),

$(\alpha \beta)_{\mathrm{ij}}=$ variation in tonal density due to combined effect of $\alpha$ and $\beta$ (hypothesis $\mathrm{c}$ ), and

$\mathrm{e}_{\mathrm{ijm}}=$ random error specific to reading $\mathrm{ijm}$.

To compile data to test the model, we assembled tonal density values for the 16 strips of experimental muskeg into eight data cells. Each cell represents either an upstream or downstream muskeg at one of four locations corresponding to the age and presence of the road in the study area. Those locations are the Mackenzie Highway, older Liard Highway, recent Liard Highway, and the undisturbed "control" muskegs (see Fig. 1). The cells were assembled into a $4 \times 2$ matrix whose dimensions correspond to differing levels of the roadbed presence and hydrologic relation to the roadbed factors respectively (Table 3).

TABLE 2. Grouping of ecological categories into spectral classes

\begin{tabular}{ll}
\hline \hline $\begin{array}{l}\text { Muskeg class based on near- } \\
\text { infrared spectral response }\end{array}$ & $\begin{array}{l}\text { Ecological category of muskeg } \\
\text { (Forestry Management Institute, 1974) }\end{array}$ \\
\hline 1. Black spruce bog & $\begin{array}{l}100 \% \text { black spruce bog } \\
\text { 2. Black spruce/ fen }\end{array}$ \\
$\begin{array}{l}70 \% \text { black spruce/ } 30 \% \text { fen } \\
60 \% \text { fen/ } 40 \% \text { black spruce }\end{array}$ \\
3. Fen & $100 \%$ fen \\
4. Sphagnum bog & $100 \%$ Sphagnum bog \\
& $60 \%$ black spruce/ $40 \%$ Sphagnum bog \\
& $70 \%$ fen/ $30 \%$ sphagnum bog
\end{tabular}

TABLE 3. Matrix of cell means ${ }^{\mathrm{a}}$ used in ANOVA-1

\begin{tabular}{lll|c|c|}
\hline \hline & & \multicolumn{3}{c}{ Levels of Factor $\beta$} \\
& & $\begin{array}{c}\text { Upstream } \\
\text { position }\end{array}$ & \multicolumn{1}{c}{$\begin{array}{c}\text { Downstream } \\
\text { position }\end{array}$} \\
\cline { 3 - 5 } & Mackenzie Highway & 1.304 & 1.283 & 1.294 \\
\cline { 3 - 5 } & Older Liard Highway & 1.226 & 1.194 & 1.210 \\
\cline { 3 - 5 } Levels of & Recent Liard Highway & 1.394 & 1.327 & 1.361 \\
\cline { 3 - 5 } & Control - no road & 1.334 & 1.337 & 1.336 \\
\cline { 3 - 5 } & Column means & 1.315 & 1.285 & \\
\hline
\end{tabular}

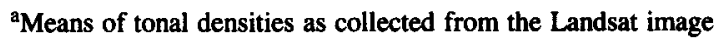

A two-way analysis of variance (Johnston, 1980) was performed on the data in the $4 \times 2$ matrix, testing the hypotheses proposed in Equation 1. This analysis of variance (ANOVA-1) provides a strong test of factor $\alpha$, while the effects of factor $\beta$ are somewhat masked.

To provide a more powerful analysis of the behaviour of factor $\beta$ we arranged the cells in a $3 \times 2$ matrix, identical to
Table 3 except that the control muskeg cells are excluded. An ANOVA performed on this matrix (ANOVA-2) provides an unmasked evaluation of factor $\beta$, though an incomplete test design for evaluation of factor $\alpha$. Between the two ANOVAs, rigorous tests of all components of Equation 1 are achieved.

For examining specific relationships among the cells, Duncan's New Multiple Range Procedure was performed on the 3 $\times 2$ matrix of cell means (Duncan, 1955). This test determines whether the difference between two cell distributions is significant, given the overall dispersion of data in the matrix. Duncan's procedure is dependent on indices of error and dispersion as calculated in ANOVA-2. The procedure was run on each possible pair of cells, testing the hypothesis that they are significantly different at the $5 \%$ level.

To identify the experimental muskegs in biophysical terms, we compared tonal density distributions of the experimental muskegs to those of the four distinguishable classes of muskeg. A $4 \times 8$ matrix was composed, its levels being the four classes and eight cells of muskeg. Because two sample sizes were being compared, the "robust" Student's t-test was used to examine each element of the matrix. Thus t-test comparisons were made between each class and each cell of muskeg. Results of the t-tests were compiled as elements of the matrix. This similiarity matrix indicates which cells of experimental muskegs are statistically similar to the classes of muskeg. The distributions of data are also shown in $95 \%$ confidence interval plots (based of pooled standard deviation), which were calculated for each class and cell. Since these plots are based on the pooled standard deviation of all classes and cells of muskeg, they illustrate the position of each class and cell in the whole array of data collected.

\section{RESULTS}

The results of the ANOVA-1 test are shown in Table 4. The test indicates that the presence of and differing ages of roadbed correspond to significantly different muskeg vegetation adjacent to the roadbed.

TABLE 4. Results of the ANOVA-1 test

\begin{tabular}{lll}
\hline \hline Factor & F ratio & Conclusion \\
\hline$\alpha$ & 7.61 & Accept at the 1\% level of significance \\
$\beta$ & 1.51 & Reject at the 5\% level of significance \\
$\alpha \beta$ & 0.3689 & Reject at the 5\% level of significance \\
\hline
\end{tabular}

The results of the ANOVA- 2 test are shown in Table 5. The test indicates that there are significant differences between upstream and downstream cells of muskeg at a given location; however, this effect is not related to the age or presence of the roadbed at the particular location.

TABLE 5. Results of the ANOVA-2 test

\begin{tabular}{lll}
\hline \hline Factor & F ratio & Conclusion \\
\hline$\alpha$ & 20.67 & Accept at the $1 \%$ level of significance \\
$\beta$ & 4.53 & Accept at the $5 \%$ level of significance \\
$\alpha \beta$ & 0.548 & Reject at the $5 \%$ level of significance \\
\hline
\end{tabular}


SIMILARITY NETWORK FOR EXPERIMENTAL MUSKEGS

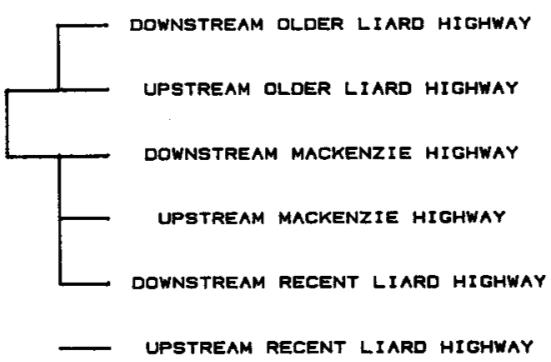

FIG. 2. Similarity network. Similarity between experimental muskegs based on the results of Duncan's New Multiple Range Procedure. Vertical connectors denote data cells found to be statistically similar at the $5 \%$ level of significance.

A similarity network compiled from iterations of Duncan's New Multiple Range Procedure performed on the ANOVA-2 data (Fig. 2) indicates that similarities are not found between the upstream muskeg at the recent Liard Highway location and the other cells. The upstream cell from the older Liard Highway is similar to the downstream cell from the Mackenzie Highway, while the downstream cell from the older Liard Highway is not. Both cells at the Mackenzie Highway site are similar to the downstream cell from the recent Liard Highway. These relationships indicate evident, but not statistically significant, differences between the upstream and downstream muskeg cells at the older Liard Highway site and significant differences between the upstream and downstream muskeg cells at the recent Liard Highway site.

The similarity matrix (Table 6) shows a classification of the experimental cells of muskeg based on their near-infrared spectral reflectance. The general distribution of tonal densities for cells and classes is shown in Figure 3. These plots provide an additional comparison of the distributions of tonal densities within the muskeg classes to those of the experimental cells. The similarity matrix indicates that both the older Liard Highway muskegs are black spruce bogs, but the confidence interval plots show a more fen-like spectral distribution in the upstream muskeg cell. The upstream recent Liard Highway cell is classified as a fen, and the downstream cell is a black spruce/fen. The two control muskeg cells can be classified as either fen or black spruce/fen and represent a mosaic of the two classes. Both the Mackenzie Highway muskeg cells are classified as black spruce/fen. No experimental muskegs are classified as Sphagnum bog. The confidence interval plots show that the spectral distributions of the upstream and downstream cells at the Mackenzie Highway site are essentially identical, as are those of the control muskeg cells.

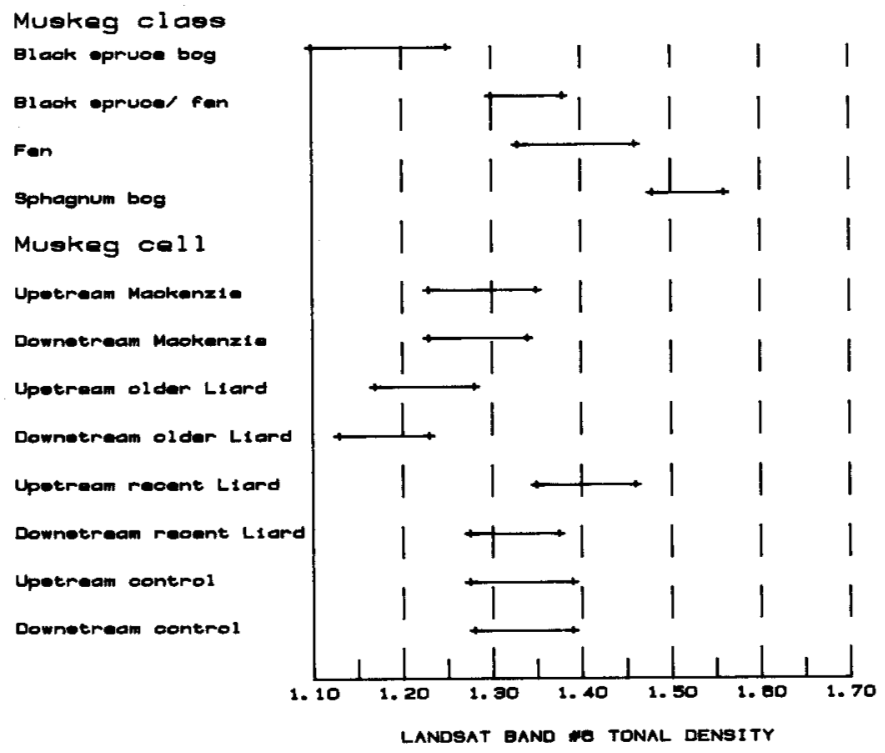

FIG. 3. Ranges of muskeg classes and cells. Ranges are based on $95 \%$ confidence intervals for means of classes and cells determined using the pooled standard deviation of classes and cells combined.

\section{DISCUSSION}

The ANOVA-1 test determined that there are significant differences among the spectral responses of muskeg vegetation for the different highway locations examined. However, the hypothesis that these differences are related to the differences between spectral responses of upstream and downstream muskegs at a location was rejected by both ANOVA-1 and ANOVA-2. Process studies of environmental impacts on muskegs suggest that surface hydrology is a major mechanism in the diffusion of an impact through a muskeg ecosystem (Radforth, 1977). When a road causes extensive change in the vegetative morphology of a muskeg, the change has differing

TABLE 6. Similarity matrix ${ }^{a}$

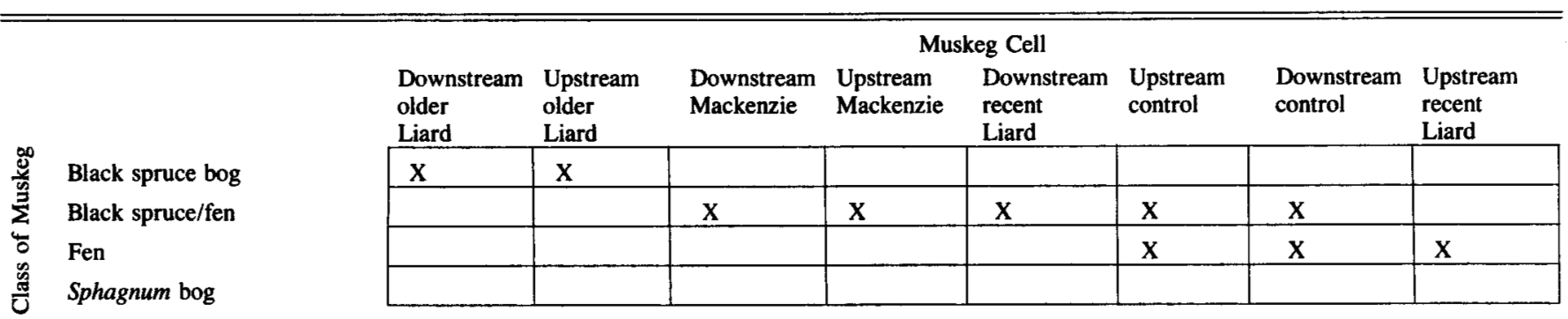

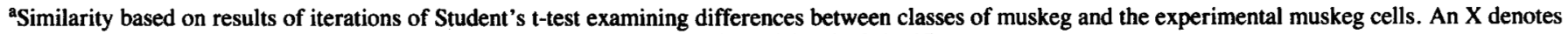
levels on the $X$ and $Y$ axes that are found to be statistically similar at the $5 \%$ level of significance. 
natures and magnitudes for muskegs upstream and downstream of the impact source. However, no relationship was found between the variance of tonal densities due to hydrologic relation to roadbeds and the gross distribution of tonal densities at various highway sites. It is likely, therefore, that differences in the gross muskeg morphology at the four study locations reflect antecedent variation, rather than an impact associated with the roadbed. The ANOVAs interpreted this as an association between road presence and age and gross vegetative morphology because of spatial autocorrelation between these two factors. Spatial autocorrelations are quite common in correlations of features associated with time over a geographic distance (Johnston, 1980). Given an autocorrelation, a further conclusion is that the antecedent variation in gross vegetative morphology is not sufficient to influence the magnitude of variation between upstream and downstream muskegs from location to location in the experimental muskegs.

The nature of the variation between upstream and downstream muskegs is therefore of primary interest and can be determined by examining the biophysical identity of this variation at specific sites. At the two locations examined along the Liard Highway there is a pronounced tendency for upstream muskegs to contain more fen than downstream muskegs. This situation is reported by the Saskatchewan Research Council (1981) as resulting from the flooding of black spruce bogs where there is potential for fen development. In muskegs containing discontinuous permafrost, such as those in the study area, flooding will cause permafrost degradation and development of thermokarst terrain in areas of black spruce bog, and a rapid transition to fen conditions (Rennie et al., 1978). Any downstream effects from the reduced transmission of water through the roadbed would not be evident until new forest communities develop. All experimental muskegs in this study are in the range of conditions from black spruce bogs to fen. Any major flooding caused by artificial damming of surficial flow by a roadbed will therefore result in an increase in the proportion of fen in muskeg upstream of the roadbed. This is the case at locations along the older and recent sections of the Liard Highway but is not the case at the study locations along the Mackenzie Highway and the control muskegs.

Factors contributing to the composition of muskegs adjacent to roads in the zone of discontinuous permafrost are, therefore: the regional variation in muskeg composition; the variation in muskeg composition resulting from the hydrologic location of the muskeg to nearby roads, when the roadbed presents a significant obstruction to surficial flows; and the random variation in muskeg composition at a particular sampling point.

\section{CONCLUSIONS}

Extensive changes in muskeg composition upstream of sites on the Liard Highway have been observed. These observations concur with reports of hydrologic regime alteration and subsequent vegetative change resulting from a linear surface obstruction near Norman Wells, N.W.T. (Soulis and Reid, 1978). Along portions of the Liard Highway, the roadbed has acted as a dike. The subsequent alteration of perpendicular surficial flows results in ponding and therefore an increase in the area of fen and a decrease in the area of black spruce. Such damming of surface flows may prove to be a factor in "washouts" of the road (Fig. 4). Apparently inadequate road design or construction has dramatically changed the land to which this road provides access. Whether these changes are beneficial or harmful to renewable resource use can only be determined by more intensive study of the impacted areas.

The Landsat data used in this pilot study are limited to measurement of gross change in the morphology of a complex ecosystem and indication of the source of the impact on the ecosystem. The statistical analysis is well suited to examine the spatial variation of diffuse impacts and can be applied in detection of other types of change. It may provide a costeffective and timely means of monitoring and documenting environmental impacts from roads, pipelines, and other extensive developments in northern regions.

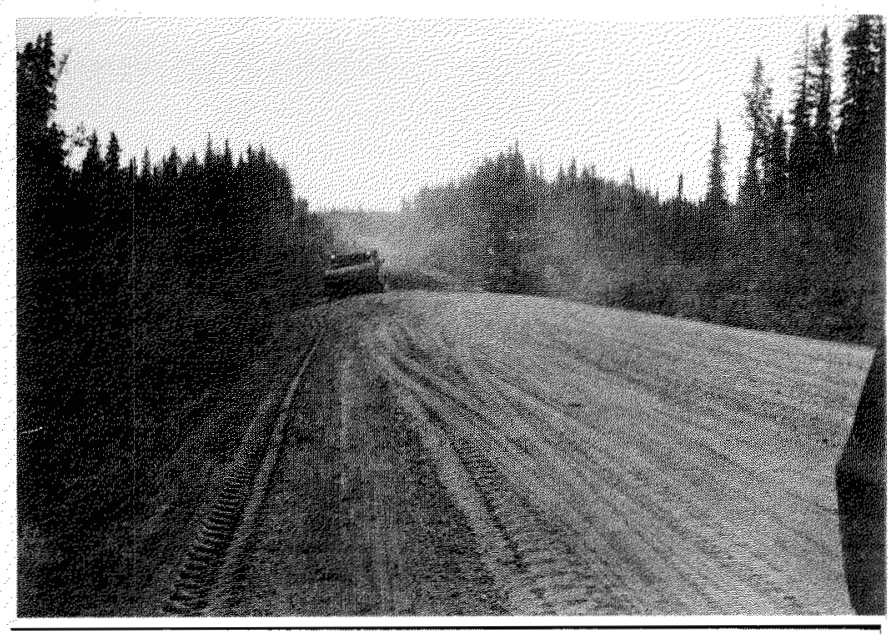

FIG. 4. Liard Highway, early June 1983. Construction in progress south of the Poplar River crossing to repair damage to the roadbed caused by spring runoff.

\section{ACKNOWLEDGEMENTS}

The author thanks Dr. K.I. Fung and the University of Saskatchewan Geography Department for providing Landsat images, computer time, and use of equipment; Dr. D.M. Gray of the Division of Hydrology, University of Saskatchewan, and anonymous referees for their critical reviews of the manuscript, and Mrs. E. Wigham, Division of Hydrology, for typing the manuscript.

\section{REFERENCES}

BROWN, R.J.E. 1977. Muskeg and permafrost. In: Radforth, N., and Brawner, C., eds. Muskeg and the Northern Environment in Canada. Toronto: University of Toronto Press. 148-163.

and PÉWE, T.L. 1973. Distribution of permafrost in North America and its relationship to the environment; a review 1963-1973. Permafrost; North American Contribution, Second International Permafrost Conference, Yakutsk, U.S.S.R. Washington: National Academy of Science Publication 2115. 71-100.

DUNCAN, D.B. 1955. Multiple range and F tests. Biometrics 11:1-42.

ENVIRONMENT CANADA. 1973. Landscape survey in the upper and central Mackenzie Valley. Ottawa: Task Force on Northern Oil Development, Report No. 73-8. 67 p.

ENVIRONMENTAL ASSESSMENT PANEL. 1981. Norman Wells Oilfield 
Development and Pipeline Project. Ottawa: Federal Environmental Assessment Review Office. 98 p.

FITZGIBBON, C.A. 1979. Environmental Protection Measures for the Development of Roads, Pipelines and Electrical Energy Transmission Lines. Saskatoon: Saskatchewan Research Council Report No. E-79-3. 308 p.

FORESTRY MANAGEMENT INSTITUTE. 1974. Vegetation types of the Mackenzie corridor. Ottawa: Task Force on Northern Oil Development, Report No. 73-46. 85 p.

FRENCH, H.M. 1976. The Periglacial Environment. London: Longman's Ltd. $309 \mathrm{p}$.

HAZENBERG, G., and CHELIAK, W. 1980. Nested classification: a five stage nested sampling design. In: Practical Applications of Remote Sensing to Timber Inventory. Edmonton: Northern Forest Research Centre, Information Report No. NOR-X-224. 86-90.

INTERDISCIPLINARY SYSTEMS LTD. 1981. Technical Report, Hire North Evaluation. Calgary: Interdisciplinary Systems Ltd. 168 p.

JOHNSTON, R.J. 1980. Multivariate Statistical Analysis in Geography. London: Longman Group Ltd. 280 p.

KREBS, P.V. 1982. Multiresource inventory and mapping of Alaska's wildlands: A cost-effective application. In: Johannsen, C.J., and Sanders, J.L., eds. Remote Sensing for Resource Management. Ankeny, lowa: Soil Conservation Society of America. 81-90.

LANDGREBE, D.A. 1978. The quantitative approach: concept and rationale. In: Swain, P., and Davis, S., eds. Remote Sensing: The Quantitative Approach. Toronto: McGraw-Hill International. 1-20.

MACFARLANE, I.C. 1969. Muskeg Engineering Handbook. Toronto: University of Toronto Press. 297 p.

MEAD, D.A. 1982. Assessing data quality in geographic information systems. In: Johannsen, C.J., and Sanders, J.L., eds. Remote Sensing for Resource Management. Ankeny, Iowa: Soil Conservation Society of America. 51-62.

QUENET, R.V. 1980. Methods of acquiring, interpreting and processing Landsat data for use in forestry. In: Practical Applications of Remote Sensing to Timber Inventory. Edmonton: Northern Forest Research Centre, Information Report No. NOR-X-224. 11-22.

RADFORTH, N.W. 1977. Muskeg hydrology. In: Radforth, N., and Brawner, C., eds. Muskeg and the Northern Environment in Canada. Toronto: University of Toronto Press. 130-147.

RENNIE, J.A., REID, O.E., and HENDERSON, J.D. 1978. Permafrost extent in the southern fringe of the discontinuous permafrost zone, Fort Simpson, N.W.T. In: Proceedings of the Third International Conference on Permafrost, Vol. 1. Ottawa: National Research Council of Canada. 438-444.

SASKATCHEWAN RESEARCH COUNCIL and WESTPLAN ASSOCIATES. 1981. Environmental Assessment for the Proposed Relocation of Highway 106 Near Big Sandy Lake. Saskatoon: Saskatchewan Research Council Publication No. C-805-52-E-81. 450 p.

SAVAGE, J.E. 1964. Location and construction of roads in the discontinuous permafrost zone, Mackenzie District, Northwest Territories. In: Proceedings of the Canadian Regional Permafrost Conference, 1-2 December 1964. National Research Council of Canada, Associate Committee on Soil and Snow Mechanics, Technical Memorandum No. 86. Ottawa: Associate Committee on Soil and Snow Mechanics. 119-131.

SOULIS, E.D., and REID, D.E. 1978. Impact of interrupting sub-surface flow in the northern boreal forest. In: Proceedings of the Third International Conference on Permafrost. Ottawa: National Research Council of Canada. Vol. 1:225-231.

SWAIN, P.H. 1978. Fundamentals of pattern recognition in remote sensing. In: Swain, P., and Davis, S., eds. Remote Sensing: The Quantitative Approach. Toronto: McGraw-Hill International Limited. 136-187. 